Acta Universitatis Wratislaviensis • No 3813

Literatura i Kultura Popularna XXIII, Wrocław 2017

DOI: $10.19195 / 0867-7441.23 .13$

\title{
Magdalena Szkwarek
}

Uniwersytet Warszawski

\section{W co grają bohaterowie literatury latynoamerykańskiej?}

Słowa kluczowe: gry, literatura, Ameryka Łacińska

Keywords: games, literature, Latin America

\section{Wstęp}

Na pytanie „po co ludzie grają?” można by najprościej odpowiedzieć „bo lubią". Opierając się na słowach Johana Huizingi, możemy stwierdzić, że gry i zabawy są odskocznią od rzeczywistości, są wolnością, są czynnością, którą c h c e m y wykonywać: „,[w]szelka zabawa jest najpierw i przede wszystkim swobodnym działaniem". Gra (zabawa)

upiększa życie, uzupełnia je i w tej właśnie mierze jest niezbędna, niezbędna jako funkcja biologiczna dla poszczególnej osoby i niezbędna dla społeczeństw z uwagi na zawarty w niej sens, ze względu na swoje znaczenie, na wartość wyrazu i z uwagi na związki duchowe i społeczne, które tworzy: słowem jako funkcja kulturowa²

Pojęcie gry zaczęto stosować „,W socjologii, psychologii i innych dyscyplinach, pojmowanych mniej lub bardziej naukowo. W kategoriach gry zostają wreszcie ujęte wszelkie interakcje społeczne i psychiczne"3.

Od czasu pojawienia się terminu „dzieło otwarte”, badając literaturę (a także inne teksty kultury), możemy spojrzeć na dane dzieło przez pryzmat gry, jaką z odbiorcą prowadzi (czy też może potencjalnie prowadzić) autor. (Do)wolność interpretacji sprzyja podejrzliwości i zastanawianiu się, w jaką grę tym razem

${ }^{1}$ J. Huizinga, Homo ludens. Zabawa jako źródło kultury, przeł. M. Kurecka, W. Wirpsza, Warszawa 2007, s. 20.

2 Ibidem, s. 23.

${ }^{3}$ A. Martuszewska, Radosne gry, Gdańsk 2007, s. 20.

Literatura i Kultura Popularna 23, 2017

(C) for this edition by CNS 
wciąga autor lub autorka swoich bohaterów i/lub czytających. Sama literatura, jak pisze Adam Elbanowski, „stała się grą, której reguły są powszechnie znane"

W literaturze latynoamerykańskiej do takich gier przyzwyczaił nas przede wszystkim Jorge Luis Borges, ale też Julio Cortázar czy Roberto Bolaño. W niniejszym artykule chciałabym jednak przyjrzeć się, w jakie gry d o sło w n i e grają bohaterowie stworzeni przez pisarzy pochodzących z Ameryki Łacińskiej.

\section{Gra w klasy}

Na pytanie postawione w tytule artykułu: ,w co grają bohaterowie literatury latynoamerykańskiej?” najprawdopodobniej pierwsza odpowiedź, jaka przyjdzie nam do głowy, będzie brzmiała: „w klasy”. Rzeczywiście, powieść Julio Cortázara Gra w klasy (Rayuela 1963, pol. 1968) stała się tzw. powieścią kultową i chyba wszyscy znają co najmniej jej tytuł. Oczywiście gra w tej powieści ma znaczenie metaforyczne, odnosi się także do sposobu czytania powieści („skacząc” po rozdziałach), ale jedna $\mathrm{z}$ bohaterek, Talita, pewnej nocy po prostu zaczyna grać w tę dziecięcą grę ${ }^{5}$ której zasady argentyński pisarz opisał następująco:

W klasy gra się małym kamyczkiem, który należy popychać czubkiem buta. Elementy gry: chodnik, kamyczek, but i piękny rysunek kredą, najchętniej kolorową. Na górze jest Niebo, na dole jest Ziemia, trudno jest trafić kamyczkiem w Niebo [...]. Powoli jednak nabiera się zręczności koniecznej, by przechodzić z jednego kwadratu do drugiego, i któregoś dnia może uda się wyjść z Ziemi i przenieść kamyczek do samego Nieba ${ }^{6}$.

Warto dodać, że motyw gry pojawiał się w innych Cortazarowskich tytułach, jak np. Wielkie wygrane czy Koniec gry, a Opowiadania zebrane zostały przez autora uporządkowane nie chronologicznie, ale tematycznie i jedna z grup opowiadań została zatytułowana właśnie Gry (dwie pozostałe grupy to Obrzędy i Przejścia).

\section{Pilka nożna}

Drugą odpowiedzią na pytanie zawarte w tytule artykułu będzie zapewne: „W piłkę nożną”. Sport ten rzeczywiście zajmuje sporo miejsca w literaturze omawianego kontynentu. Taki stan rzeczy nie powinien dziwić, gdy weźmiemy pod uwagę, że (podobno) „Bóg jest Brazylijczykiem” oraz to, że — jak pisze Justyna Olko — w pelotę grali już Olmekowie (najstarsze boisko odkryte w Chiapas datuje się na

\footnotetext{
${ }^{4}$ A. Elbanowski, Świadectwa, metafory, fabulacje: współczesna literatura Ameryki Łacińskiej,
} Warszawa 2013, s. 267.

${ }^{5}$ J. Cortazár, Gra w klasy, przeł. Z. Chądzyńska, Warszawa 2004, s. 302.

6 Ibidem, s. 208. 
ok. 1200-1400 r. p.n.e.), a najstarsze figurki graczy pochodzą z ok. 1500 r. p.n.e. ${ }^{7}$ Futbol to część rzeczywistości latynoamerykańskiej, chociaż warto pamiętać, że

są kraje, a nawet całe regiony, np. Karaiby, gdzie futbol nie budzi takich emocji, jak chociażby w Argentynie. Jego funkcję pełni baseball, który narodził się w Stanach Zjednoczonych, by jeszcze w XIX w. upowszechnić się w krajach karaibskich, np. na Kubie, której kultura, do czasu zwycięstwa rewolucji w 1959 r., rozwijała się pod wpływem północnego mocarstwa. Następnie Kubańczycy spopularyzowali baseball na Dominikanie, Portoryko czy w Wenezueli. Jednakże większość mieszkańców Ameryki Łacińskiej niezmiennie kocha futbol ${ }^{8}$.

Pisarze również kochają ten sport, choć — jak twierdzi peruwiański pisarz Santiago Roncagliolo - dopiero od niedawna. W jednym z wywiadów powiedział:

Literatura zawsze zapominała o futbolu, bo był plebejski [...]. W ostatnich dekadach pisarze przestali się wywyższać, już nie mówią z piedestału o kulturze wysokiej, i zaczęli dostrzegać bardziej realne, codzienne życie. A jeśli mowa o życiu codziennym, to zawsze skończy się na rozmowie o piłce nożnej ${ }^{9}$.

W 2011 r. w Bogocie wydano zbiór opowiadań i anegdot pt. El futbol se lee (dosłownie Futbol się czyta). Wśród pisarzy, których teksty znalazły się w antologii, jest m.in. znana polskim czytelnikom Laura Restrepo. Z kolei w Chile, w roku 2013, ukazał się zbiór opowiadań El futbol también se lee (Futbol także się czyta), zawierający dwadzieścia tekstów wyróżnionych w krajowym konkursie na opowiadania, których tematem jest piłka nożna. Przykłady można mnożyć, wspominając choćby Dios es redondo (Bóg jest okrągły) meksykańskiego pisarza Juana Villoro czy też Lo raro empezó después: cuentos de fútbol y otros relatos (To, co dziwne, zaczęło sie potem: opowiadania o futbolu $i$ inne historie) Argentyńczyka Eduardo Sacheriego (w jego powieści pt. Kartki na wietrze - Papeles en el viento 2011, pol. 2015 — także pojawia się wątek piłkarski). Nie można też nie wspomnieć o Eduardo Galeano i jego Blaskach i cieniach futbolu (El futbol a sol y sombra 1995, pol. 2012). Autor, który ,jak wszyscy Urugwajczycy chciał zostać piłkarzem", za pomocą krótkich form literackich pokazuje dzieje piłki nożnej, opowiada jej historię, przytacza anegdoty i opowieści o piłkarzach.

Z kolei bohater Reputacji (Las reputaciones 2013, pol. 2015) kolumbijskiego pisarza Juana Gabriela Vásqueza, karykaturzysta Javier Mallarino, słucha transmisji z meczu piłki nożnej w radio. Nie wiadomo, czy sam gra, pewne jest natomiast, że grywa w wojnę „starą talią kart z wygniecionymi rogami” ze swoją

7 Por. J. Olko-Bajer, In tlachtli In ollamaliztli. Mezoamerykańska gra w piłke, „Czas Kultury” 2006, nr 2 (131), s. 39-46.

${ }^{8}$ I. Gawrycka, Fenomen futbolu latynoamerykańskiego, [w:] Dzieje kultury latynoamerykańskiej, red. M.F. Gawrycki, Warszawa 2009, s. 504.

${ }^{9}$ Por. http://www.abc.es/cultura/cultural/20140512/abci-entrevista-santiago-roncagliolo-201405121206.html (dostęp: 30.06.2016).

Literatura i Kultura Popularna 23, 2017

(C) for this edition by CNS 
córką Beatriz, „choć tłumaczył jej tysiące razy, że gra w wojnę w dwie osoby nie jest ani trochę zabawna"10.

W ,nogę" grają za to tytułowe Szczeniaki Mario Vargasa Llosy (Los cachorros 1967, pol. 1973): „[1]ekcje kończyły się o czwartej, a o czwartej dziesięć Brat Lucio pozwalał się rozejść i o czwartej piętnaście byli już na boisku" ${ }^{\prime 1}$. Trenowali, żeby grać w reprezentacji klasy, choć jeden z chłopców, Cúellar, ,przez naukę zaniedbuje sport" 12 , co martwi jego kolegów. Zupełnie niepotrzebnie, bo ten „tak przetrenował całe lato, że następnego roku zdobył sobie w klasowej reprezentacji miejsce lewego łącznika" ${ }^{3}$. Z czasem coraz rzadziej grywali w piłkę, za to „kiedy przyjęcia urodzinowe zaczęły być przyjęciami mieszanymi, zostawali w ogrodzie, udając, że grają w raz, dwa, trzy, baba jaga patrzy, głuchy telefon czy w berka, zbity!"14. Wszystko po to, żeby z ogrodu podglądać, co dziewczyny robią z chłopcami w salonie. Wtedy też postanowili nauczyć się tańczyć: „,[p]rzedtem najbardziej na świecie uwielbialiśmy sport i kino i dawali wszystko za mecz piłki nożnej, a teraz najważniejsze były dziewczyny i taniec"15.

Inny mieszkaniec Limy, bohater powieści Noc jest dziewica Jaime Bayly’ego (La noche es virgen 1997, pol. 2007), Gabriel — „snob, gwiazda peruwiańskiej telewizji, bohater tysiąca plotek, syn dewotki i konserwatysty" (jak dowiadujemy się z okładki książki) — również nie poświęcił się piłce nożnej. Chociaż „w cholerę lat temu" grał w reprezentacji szkoły ${ }^{16}$, to teraz jednak bardziej zajmują go koka, nocne kluby, chłopcy (najlepiej blond i „przypakowani”) oraz od czasu do czasu dziewczyny. Jednak futbol nie jest mu całkowicie obojętny — z okazji mundialu w Hiszpanii kupił sobie nawet telewizor, ale jak sam mówi, „do dziś mnie bolą polskie gole"17. Na jednej z uliczek Miraflores spotyka przypadkiem Pepe Málagę, świetnego piłkarza, „który pokazał światową klasę w różnych, bardzo prestiżowych rozgrywkach, w tym oczywiście w bardzo popularnym corocznym turnieju karmelitów, gdzie gra się futbol akrobatyczny na najwyższym poziomie" ${ }^{18}$. Spotkanie jest okazją do krótkiej refleksji:

ach, jakie piękne było życie kiedy Peru występowało na mundialach, popisywało się tymi swoimi piruetami, a potem i tak ładowali nam osiem goli i eliminowali nas w atmosferze skandalu (i z podejrzeniami o przekupstwo), ale przynajmniej przechodziliśmy do drugiej rundy, cholera ${ }^{19}$.

10 J.G. Vásquez, Reputacje, przeł. K. Okrasko, Kraków 2013, s. 126.

11 M.V. Llosa, Wyzwania. Szczeniaki, przeł. C. Marrodán Casas, A. Nowak, Warszawa 2000, s. 108.

12 Ibidem, s. 109.

13 Ibidem, s. 110.

14 Ibidem, s. 119.

15 Ibidem, s. 120.

16 J. Bayly, Noc jest dziewica, przeł. T. Pindel, Kraków 2007, s. 119.

17 Ibidem, s. 27; w fazie grupowej Polska pokonała Peru 5:1.

18 Ibidem, s. 36.

19 Ibidem. 
Inaczej potoczyła się historia stworzonego przez chilijskiego pisarza Roberto Bolaño niejakiego Acevedo, bohatera (i narratora) opowiadania pt. Buba (2001, pol. 2013), który został zawodowym piłkarzem. Już w wieku dziewiętnastu lat został przyjęty do klubu Gimnasia y Esgrima ${ }^{20}$, grał w Chile oraz w Argentynie. Jego pierwszy europejski angaż to pozycja lewego skrzydłowego w drużynie w Barcelonie, której nie najlepiej idzie w rozgrywkach, o czym informuje nas sam Acevedo: „po dziesięciu fatalnych kolejkach znajdowaliśmy się w połowie tabeli, i to z tendencją raczej spadkową niż zwyżkową"21. Zła passa katalońskiego klubu odmienia się jednak wraz z pojawieniem się tytułowego Buby, który „stał się gwiazdą sezonu, królem strzelców hiszpańskiej ligi i Ligi Mistrzów"22. Czy afrykański zawodnik był wirtuozem piłki czy szarlatanem? Magikiem czy szaleńcem? Nie wiemy, Acevedo też tego nie wiedział, ale nie rozmyślał o tym wiele, konstatując jedynie, że „futbol jest dziwny"23. Po przejściu do Juventusu Buba nadal odnosił sukcesy, do czasu gdy „zginął w wypadku samochodowym w drodze na lotnisko w Turynie"24.

Inny Bolañowski bohater, Roger Strada, mieszkaniec Moskwy „narkotyków i prostytucji, czarnego rynku i zabawy, gróźb i przestępstw" 25 , co prawda nie grał „w nogę", ale zajmował się zakładami sportowymi:

Piłka nożna, hokej, koszykówka, boks, nawet zawody narciarskie, czyli dyscyplina sportowa, której sensu nigdy nie pojmowałem, wszystkim się zajmowaliśmy. I poznawałem ludzi. Ludzi wszelkiego autoramentu. Na ogół sympatyczne typy, pomniejsi kryminaliści, tacy jak ja, ale zdarzało mi się poznać też prawdziwych przestępców, ludzi gotowych na wszystko, albo takich, którzy w jaki m ś mo me n c i e byliby gotowi na wszystko ${ }^{26}$.

Roger Strada poznał tak Miszę Siemionowicza Pawłowa i zaczął dla niego pracować:

Czasami posyłał mnie do jakiegoś znajomego zawodnika z plikiem banknotów, żeby przegrał mecz. Za jednym razem udało mi się przekupić połowę drużyny piłkarskiej, jednego po drugim, podlizując się wrażliwszym i grożąc dyskretnie bardziej butnym. Kiedy indziej zajmowałem się przekonywaniem innych stawiających, żeby się wycofali z zakładów albo nie robili zamieszania. Ale przez większą część czasu zajmowałem się dostarczaniem raportów na temat sportowców ${ }^{27}$.

Po wielu perypetiach, pobycie we Frankfurcie i Stuttgarcie Roger wyjechał do Barcelony, ale nocami tęsknił za Moskwą: ,„[t]u nie jest źle, ale to nie to samo, choć gdybyś mi kazał mówić precyzyjniej, to bym nie umiał wyjaśnić, czego właściwie mi brakuje"28.

${ }^{20}$ R. Bolaño, Buba, [w:] idem, Dziwki morderczynie, przeł. T. Pindel, Warszawa 2013, s. 140.

21 Ibidem, s. 146.

22 Ibidem, s. 158.

23 Ibidem, s. 155.

24 Ibidem, s. 159.

25 R. Bolaño, Śnieg, [w:] idem, Rozmowy telefoniczne, przeł. T. Pindel, Warszawa, 1997, s. 88.

26 Ibidem, s. 88.

27 Ibidem, s. 90.

28 Ibidem, s. 101. 
Może nostalgia Strady za starymi czasami byłaby mniejsza, gdyby wiedział to, czego dowiedział się Bustos Domecq (bohater stworzony przez Jorge Luisa Borgesa i Adolfo Bioy Casaresa), który w opowiadaniu Esse est percipi (1967, pol. 1985) ze zdziwieniem zauważył, że w dzielnicy Nuñez zniknął ze swego miejsca monumentalny stadion River. Chcąc się dowiedzieć, co się stało, spotkał się z prezesem klubu Abasto Juniors, Tulio Savastanem, kolegą z dzieciństwa. Ten rzeczowo wyjaśnił:

Nie ma scorów, nie ma ekip ani meczów. Stadiony są już nieczynne i rozsypują się w gruzy. Dziś wszystko dzieje się w telewizji i radio. Czyżby fałszywe podniecenie spikerów nigdy nie kazało panu podejrzewać, że wszystko to lipa? Ostatni mecz piłki nożnej został rozegrany w tym mieście w dniu 24 lipca 1937 roku. Dokładnie od tego momentu piłka nożna, podobnie jak cała gama innych sportów, jest gatunkiem dramatycznym realizowanym przez jednego tylko człowieka w kabinie czy przez aktorów w podkoszulkach przed kamerą ${ }^{29}$.

Ta gra przyciąga jednak niezmiennie np. mieszkańców Bogoty, o których pisze Santiago Gamboa w powieści Trzeba umieć przegrywać (Perder es cuestión de método 1997, pol. 2010): „[c]ałe miasto wlepiło wzrok w ekrany telewizorów, śledząc mecz o Puchar Wyzwolicieli Ameryki" ${ }^{30}$. Wspomniany już Gabriel z powieści Noc jest dziewica twierdził, że pogoda, polityka i piłka nożna to trzy uniwersalne tematy, „kiedy za cholerę nie ma o czym gadać” 31 , i jakby na potwierdzenie tej tezy, bogotański taksówkarz w powieści Gamboi wspominał rozemocjonowany, zwracając się do pasażera: ,[p]amięta pan ten strzał w słupek? Ja to widziałem i nawet krzyknąłem, że padł gol! Kurwa, już była prawie w bramce! I kiedy się odbiła, kurwa, wrzasnąłem na całe gardło..."32.

„W nogę” gra się też na emigracji, np. w Nowym Jorku. „Kolumbijczycy grają z Kolumbijczykami. Jak zawsze my sami przeciwko sobie"33 — zauważa Marlón, bohater powieści Paraíso Travel (2002, pol. 2006). Z kolei w jednym z gwatemalskich miasteczek, w którym rozgrywa się akcja Głuchych (Los sordos 2012, pol. 2014), co prawda nikt się tak nie emocjonuje piłką nożną, ale z plażą sąsiaduje boisko $^{34}$, więc możemy przypuszczać, że i tam od czasu do czasu odbywają się mecze.

\section{Inne gry zespołowe}

Ci, którzy grać w piłkę nożną nie chcą lub nie mogą, mają inne dyscypliny sportowe do wyboru. Kubańscy bohaterowie prozy Leonardo Padury grają w baseball, ponieważ ,nie było po prostu lepszego zajęcia niż rozegranie meczu baseballu, który zaczynał się w gorącym słońcu popołudnia i trwał do późnego

29 J.L. Borges, A.B. Casares, Esse est percipi, [w:] Kroniki Bustosa Domecqa, przeł. J. Kühn, A. Sobol-Jurczykowski, Kraków-Wrocław 1985, s. 77.

30 S. Gamboa, Trzeba umieć przegrywać, przeł. T. Tomczyńska, Warszawa 2010, s. 197.

31 J. Bayly, op. cit., s. 31.

32 S. Gamboa, op. cit., s. 285.

33 J. Franco, Paraíso Travel, przeł. T. Pindel, Wołowiec 2006, s. 143.

34 R. Rey Rosa, Gtusi, przeł. B. Jaroszuk, Warszawa 2012, s. 235.

Literatura i Kultura Popularna 23, 2017

(C) for this edition by CNS 
wieczoru" ${ }^{35}$, a Alberto z paragwajskiej powieści Zima Guntera (El invierno de Gunter 1987, pol. 2015) należy do drużyny rugby ${ }^{36}$.

Część bohaterów wybiera tenis, tak jak bohater Filmów mojego życia Alberto Fugueta (Las peliculas de mi vida 2003, pol. 2008) czy też wywodzący się z klasy wyższej mieszkańcy zamkniętego osiedla Altos de la Cascada, bohaterowie Czwartkowych wdów Claudii Piñeiro (Las viudas de los jueves 2005, pol. 2015). Tano i Gustavo grali zawsze w soboty o dziesiątej rano. „Kiedy grali, zawsze zbierała się publiczność, zawsze był ktoś, żeby potem opowiadać o nowym wyczynie" 37 . Tano grywał też w golfa, choć „nie przepadał za tym sportem i nie miał tak dobrych wyników jak w tenisie" 38 , ale spotkania na polach golfowych były okazją do omówienia ważnych spraw i planowania interesów. O klubie golfowym wspominał również Gabriel ${ }^{39} \mathrm{z}$ Noc jest dziewica.

Zarówno tenis, jak i golf są dyscyplinami dla wybranych, dla elity, wymagają nakładów finansowych, odpowiedniego sprzętu, ubioru oraz składek członkowskich we właściwych klubach. W przeciwieństwie do bilardu, w którego mogą grać wszyscy.

Spotkanie przy bilardowym stole było początkiem znajomości między Ricardo Laverde a Antonio Yammarą, wykładowcą uniwersyteckim, narratorem i bohaterem powieści Hałas spadających rzeczy (El ruido de las cosas al caer 2011, pol. 2013). Stół bilardowy znajduje się też na okładce polskiego wydania powieści kolumbijskiego pisarza Juana Gabriela Vásqueza. Przypadkowe spotkanie w lokalu przy Czternastej Ulicy będzie miało długotrwałe konsekwencje. Wspólna gra zbliża do siebie bohaterów, chociaż Laverde prosi Yammarę, by ten nie mylił bilardu z przyjaźnią. Przy okazji dowiadujemy się, że dla części Bogotańczyków - przyzwyczajonych do przemocy i doniesień o kolejnych porwaniach i zamachach — bilard stał się odskocznią od krwawej rzeczywistości, czymś, co łączy i jednoczy, a jednocześnie choć na chwilę pomaga zapomnieć: „z rezygnacją mającą w sobie już coś z narodowego rytuału, złorzeczyliśmy i przeklinaliśmy kolejną zbrodnię, takie piętno naszych czasów"40.

Również przy bilardzie Victor Silampa, inny kolumbijski bohater, spotyka się ze swoim informatorem i załatwia interesy — w sali bilardowej Caracas, mieszczącej się przy ulicy Pięćdziesiątej Siódmej lub też w barze Lolita. W salonie gier w tym drugim miejscu ,przy czteroosobowych stołach grano w karty, domino i kości, wszędzie leżały banknoty i żetony, kostki i plansze"41.

35 L. Padura, Trans w Hawanie, przeł. M. Sarna, Kraków 2010, s. 13.

36 J. Manuel Marcos, Zima Guntera, przeł. K. Pisera, Warszawa 2015.

37 C. Piñeiro, Czwartkowe wdowy, przeł. T. Pindel, Katowice 2015, s. 145.

38 Ibidem, s. 267.

39 Por. J. Bayly, op. cit., s. 50.

40 J.G. Vásquez, Hałas spadajacych rzeczy, przeł. T. Pindel, Warszawa 2013, s. 15.

41 S. Gamboa, op. cit., s. 44. 


\section{Gry planszowe}

Nie trzeba jednak wychodzić z domu do baru Lolita (,który śmierdział szczynami kotów"42), żeby grać w gry planszowe.

Motywem powtarzającym się w wielu tekstach są szachy. W szachy grają dwaj mężczyźni w biurze, do którego zostaje wprowadzony bohater Martwego portu Juana Carlosa Onettiego ${ }^{43}$ (El astillero 1967, pol. 1975), Bacon, postać stworzona przez Jorge Volpiego w powieści Na tropie Klingsora (En busca de Klingsor 1999, pol. 2002), pyta o grę w szachy Linksa i proponuje mu w przyszłości wspólną partyjkę ${ }^{44}$, a w Stu latach samotności (Cien años de soledad 1967, pol. 1974) generał Moncada uczy grać w szachy pułkownika Aureliano Buendięę5. Warto dodać, że inni bohaterowie powieści grywali też w warcaby, także Amaranta, która wspominała popołudnia spędzone na grze z pułkownikiem Gerineldim Marquezem ${ }^{46}$ (według słów Paula Ricoeura, „kultywowała dzieło pamięci, ażeby spowolnić zapomnienie czy wręcz je powstrzymać" ${ }^{7}$. Nie odwzajemniła miłości pułkownika, ale przypominając sobie wspólnie spędzony czas, zaczęła za nim tęsknić, a nawet pożądać go).

Sporo miejsca szachom poświęca w swoich utworach Jorge Luis Borges, w tę królewską grę grają również bohaterowie Sztucznego oddychania Ricardo Pigli (Respiración artificial 1980, pol. 2009). Jeden z nich to Polak, Tardewski ${ }^{48}$ — ,prawdziwy mistrz. Grywał dawniej z samym Alechinem i Jamesem Joyce'em w Zurychu — remis z nim to jedno z marzeń mojego życia"49 — informuje narrator.

Fundamentalne znaczenie mają szachy w powieści Amphitryon (2000, pol. 2004), której autorem jest Ignacio Padilla. Rozgrywana partia szachów staje się grą hazardową, której stawką jest tożsamość bohaterów:

Prawdziwy szachista — powtarzał mój ojciec za każdym razem, gdy objaśniał mi jakieś mistrzowskie posunięcie — potrafi natychmiast, nawet w najdziwniejszych okolicznościach, rozpoznać równego sobie, jednak nie zasiądzie do szachownicy, dopóki dobrze nie oszacuje sił przeciwnika, a już na pewno nigdy, naprawdę nigdy, za stawkę w tej boskiej grze nie przyjmie niczego mniej ważnego niż własne życie [...]. Zasady partii zostały ustalone z klarownością zupełnie niepasującą do mglistej atmosfery spowijającej resztę tej historii: jeśli ojciec wygrałby, tamten człowiek miał go zastąpić na froncie wschodnim i oddać mu posadę zwrotniczego [...]. Jeśliby jednak przegrał, miał, zanim pociąg dojedzie do celu, strzelić sobie w łeb ${ }^{50}$.

42 Ibidem, s. 43.

43 Por. J.C. Onetti, Martwy port, przeł. T. Marzyńska, Kraków 1975, s. 152.

44 Por. J. Volpi, Na tropie Klingsora, przeł. F. Łobodziński, Warszawa 2002, s. 181.

45 Por. G. García Márquez, Sto lat samotności, przeł. G. Grudzińska, K. Wojciechowska, Warszawa 1999, s. 161.

46 Ibidem, s. 165.

47 P. Ricoeur, Pamięć, historia, zapomnienie, przeł. J. Margański, Kraków 2007, s. 563.

${ }^{48} \mathrm{Z}$ okładki polskiego wydania powieści dowiadujemy się, że Tardewski wzorowany był na Witoldzie Gombrowiczu.

49 R. Piglia, Sztuczne oddychanie, przeł. B. Jaroszuk, Warszawa, 2009, s. 16.

${ }^{50}$ I. Padilla, Amphitryon, przeł. M. Płachta, Warszawa, 2004, s. 15.

Literatura i Kultura Popularna 23, 2017

(C) for this edition by CNS 
Thadeus Dreyer zamienił się tożsamością z Viktorem Kretzschmarem, a wątek utraty tożsamości przewijać się będzie przez całą powieść, prowadząc nas od fikcyjnych bohaterów do postaci Adolfa Eichmanna — „nawiasem mówiąc znakomitego szachisty" "51. Życie ludzkie jest rozgrywką na szachownicy, z tym że w tym wypadku nie jest to tylko metafora.

Inne połączenie gry i życia proponuje Roberto Bolaño w powieści zatytułowanej Trzecia Rzesza (El Tercer Reich 2010, pol. 2011). Trzecia rzesza to nazwa gry, w którą gra bohater powieści, Udo, mistrz gier strategicznych. Gry go pochłaniają, są obecne na jawie i we śnie: „[o]d paru lat śnią mi się gry. Kładę się, zamykam oczy, a wtedy zapala się plansza pełna niezrozumiałych figur i - tak ukołysany — zasypiam"52 — czytamy w jego dzienniku i coraz bardziej przekonujemy się, że wakacyjna gra stopniowo wkracza w rzeczywistość bohatera, zmieniając go pod koniec powieści... ${ }^{53}$

Gry planszowe lubią zarówno dorośli, jak i dzieci, a przykładem może być młody kubański bohater powieści Carlosa Eire Czekając na śnieg w Hawanie (Waiting for Snow in Havana 2003, pol. 2005), który ma w domu monopol, szachy, warcaby, parcheesi oraz chińczyka ${ }^{54}$. Co prawda spoczywają one na półce, ale domyślamy się, że nie są tylko ozdobą.

\section{Gry komputerowe}

Młodzi współcześni bohaterowie latynoamerykańscy, idąc z duchem czasu i postępem technologicznym, wybierają gry komputerowe. Bohaterowie Diabła stróża Xaviera Velasco (Diablo guardián 2003, pol. 2016), Violetta i Eric, spędzają całe dnie i noce, grając w gry wideo ${ }^{55}$. Podobnie Gabriel z Noc jest dziewica — całymi dniami gra w Pacmana. Jak sam mówi:

jestem ofiarą nieszczęsnego nałogu pacmanii, każdy, kto w to grał, mnie zrozumie: ma coś cholernie narkotycznego ta gierka [...]. Tak dużo grałem przez cały cholerny dzień, że czasami nocą nie mogłem spać. Zamykałem oczy i widziałem w głowie ekran i ścigające mnie potworki, a ja uciekałem przez syfiasty labirynt, który znałem już na pamięć. Nie ma szans,

51 Ibidem, s. 171

52 R. Bolaño, Trzecia Rzesza, przeł. M. Szafrańska-Brandt, Warszawa 2011, s. 42.

53 Dwie ostatnie powieści można odczytać, odwołując się do kategorii pojęciowych Jeana Baudrillarda (przede wszystkim „symulacji” i „symulakrów”). Francuski myśliciel mówi bowiem o zacieraniu się granicy między pierwowzorem a kopią, między tym, co „prawdziwe”, a tym, co wytworzone (por. idem, Precesja symulakrów, przeł. T. Komendant, [w:] Postmodernizm. Antologia przekładów, red. R. Nycz, Kraków 1997, s. 178-179). Kopie mogą istnieć bez oryginałów (,precesja symulakrów”), stają się wówczas od nich doskonalsze. Symulacja prowadzi do zanikania rzeczywistości (por. A. Ziętek, Jean Baudrillard wobec wspótczesności. Polityka, media, społeczeństwo, Kraków 2013, s. 24-25).

54 Por. C. Eire, Czekając na śnieg w Hawanie, przeł. T. Bieroń, Poznań 2005, s. 94.

55 Por. X. Velasco, Diabet stróż, przeł. M. Olejnik, Katowice 2016, s. 157.

Literatura i Kultura Popularna 23, 2017

(C) for this edition by CNS 
żeby sobie wybić z głowy tego pieprzonego pacmana. Przysięgam wam, życie z tą dyskietką w mózgu przypomina koszmar. Tak jak mówiłem, to narkotyk ${ }^{56}$.

„Życie staje się nagle grą wideo, której nie możesz wyłączyć. I musisz szybko biec, zanim to ono wyłączy Ciebie"57 — zdaje się wtórować Gabrielowi wspomniana Violetta.

Dołączyłby do nich zapewne Oscar, Dominikańczyk, bohater powieści Junota Díaza Krótki i niezwykty żywot Oscara Wao (The Brief Wondrous Life of Oscar Wao 2007, pol. 2009). Oscar to mały dziwoląg, który

potrafił pisać w języku elfów, mówić w chakobsa, znał różnicę między Slanem, Dorsajem i Lensmanem [...] i był fanatykiem RPG. (Gdyby tylko lepiej sobie radził z grami wideo, byłoby super, ale chociaż był właścicielem atari i konsoli Intellivision, nie miał do nich odpowiedniego refleksu) ${ }^{58}$.

Gry rekompensowały mu nieciekawą i trudną rzeczywistość, ale do czasu:

pewnego dnia wszedł do Game Room i z zaskoczeniem odkrył, że nagle nowe pokolenie maniaków nie kupuje już gier RPG. Mają obsesję na punkcie kart Magic! Nikt tego nie przewidział. Koniec z bohaterami i kampaniami, jedynie niekończące się bitwy między taliami. Gry ogołocone z narracji, tylko zwykła, prosta mechanika. Jak te małolaty uwielbiały ten szajs! Chciał sam spróbować zebrać porządną talię, ale to po prostu nie było dla niego. Przegrał wszystko z jedenastoletnim gówniarzem i stwierdził, że ma to gdzieś. Pierwsza oznaka, że jego czas dobiega końca. Kiedy najnowsze atrakcje już nie rajcują, kiedy nad nowe przedkłada się stare ${ }^{59}$.

\section{Podsumowanie}

Wybrane przykłady pokazują, że bez względu na kraj pochodzenia oraz status społeczny bohaterowie literatury latynoamerykańskiej lubią spędzać czas, grając. Gry pojawiają się w powieściach, opowiadaniach i wierszach.

Czasem motyw gry jest tylko wtrąceniem, luźnym skojarzeniem, czasem stanowi główną oś tekstu. Grając, bohaterowie relaksują się i odpoczywają, spędzając wolny czas w towarzystwie przyjaciół, albo też prowadzą przy grach biznesowe rozmowy i interesy.

Pisarze opisują w tekstach gry ruchowe, takie jak popularna i powszechnie dostępna piłka nożna, oraz gry dla wybranych, np. golf. Ci, którzy nie przepadają za grami sprawnościowymi na świeżym powietrzu, mogą zagrać w „planszówki”. Motywem powtarzającym się u wielu autorów są szachy. Uniwersalność tej królewskiej gry sprawia, że grali w nią zarówno bohaterowie powołani do życia na początku wieku, jak i bohaterowie współcześni. W artykule wymieniłam tylko kilku, ale jest ich o wiele więcej.

56 J. Bayly, op. cit., s. 54; pisownia oryginalna.

57 X. Velasco, op. cit., s. 188.

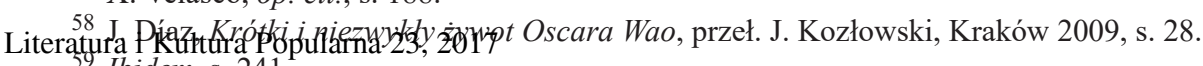

(c) for thitsidgitior by by $^{2}$ eNs 
Rozwój technologii i pojawienie się gier komputerowych sprawiły, że do literatury dostał się m.in. Pacman, a rozwój gier fabularnych spowodował, że również literaccy bohaterowie interesują się grami RPG.

Powszechność czynności, jaką jest granie i fenomen gier, spowodowały, że motyw gry był obecny u wielkich, znanych i uznanych twórców regionu, takich jak Jorge Luis Borges czy Mario Vargas Llosa, sztandarowych przedstawicieli realizmu magicznego, jak Gabriel García Márquez, i tych, którzy ten realizm krytykowali, jak Roberto Bolaño. Gier w narracji używają również przedstawiciele nowych nurtów w literaturze latynoamerykańskiej: nurtu $\mathrm{McOndo}^{60}$, który reprezentują m.in. Alberto Fuguet i Jaime Bayly, oraz pisarze należący do pokolenia Crack $^{61}$ : Ignacio Padilla czy Jorge Volpi.

\title{
What games do the characters in Latin American literature play?
}

\author{
Summary
}

The "open text" concept allows us to look at the literary work through the prism of the game which an author plays (or could potentially play) with a recipient. However, in my article I would like to show what games (literally!) play the fictional characters created by authors from Latin America, namely: board games, games involving physical stimulation, group games, video games, etc. Regardless of the origin and social status, the characters in Latin American literature enjoy playing games, as we shall see by analyzing selected texts.

${ }^{60}$ Mianem McOndo określa się zarówno grupę literacką, jak i nurt w literaturze latynoamerykańskiej. Za początek zjawiska przyjmuje się 1996 r., w którym wydano antologię młodych pisarzy zatytułowaną McOndo. Autorzy odcinają się przede wszystkim od realizmu magicznego (i Marquezowskiego Macondo) jako fałszującego rzeczywistość latynoamerykańską; postulują opisywanie rzeczywistości takiej, jaką jest. Proponują także skupić się na tożsamości indywidualnej, a w ich twórczości nie ma miejsca na zaangażowanie społeczno-polityczne i koloryt lokalny (por. A. Elbanowski, op. cit., s. 266-267).

${ }^{61}$ Mianem tym określa się grupę twórców meksykańskich, którzy proponowali powrót do tradycji boomu, czyli do literatury ambitnej, głębokiej, oryginalnej, dla wymagających czytelników, których nie zadowalają proste fabuły. Manifest Cracku ogłoszono w 1996 r. (por. T. Pindel, Realizm magiczny. Przewodnik (praktyczny), Kraków 2014, s. 84-85). 